\title{
APLIKASI BIOCHAR SEKAM PADI DAN BAKTERI PELARUT FOSFAT Paenibacillus sp. PADA TANAMAN CABAI MERAH (Capsicum annum L) DI MEDIUM ULTISOL
}

\author{
The Application of Rice Husk Biochar and Phosphate Solubilizing Bacteria \\ Paenibacillus Sp. on The Red Chili Plants (Capsicum annum L) in Ultisol Medium
}

\author{
Beatrix Stella Marien Simamora, Zulfatri, Armaini \\ Jurusan Agroteknologi, Fakultas Pertanian, Universitas Riau \\ Email: Beatrix.stella@gmail.com/082367896070 \\ [Diterima: Oktober 2021; Disetujui: Desember 2021]
}

\begin{abstract}
Red chili is a commodity that must be developed in the Riau, which is mostly ultisol soil. Rice husk biochar as an ameliorant can increase plant growth. Also the bacteria Paenibacillus sp. can solubilize unavailable phosphate to become available for red chili plants. This study aimed to know the best doses between the combination of rice husk biochar and phosphate solubilizing bacteria Paenibacillus sp. on the growth of red chili plants. The study was conducted at the experimental farm of the Faculty of Agriculture, the University of Riau from January to May 2021, using non-factorial and randomized completely design, then tested with Duncan's new multiple range test (DNMRT). The combination factor is rice husk biochar and phosphate solubilizing bacteria Paenibacillus sp.: 0 g/polybag $+0 \mathrm{ml}$ (B1); 0 g/polybag $+15 \mathrm{ml}(\mathrm{B} 2) ; 0 \mathrm{~g} / \mathrm{polybag}+30 \mathrm{ml}$ (B3); $0 \mathrm{~g} /$ polybag $+45 \mathrm{ml}$ (B4); $210 \mathrm{~g} /$ polybag $+0 \mathrm{ml}$ (B5); $210 \mathrm{~g} /$ polybag $+15 \mathrm{ml}$ (B6); 210 g/polybag + $30 \mathrm{ml}$ (B7); $210 \mathrm{~g} /$ polybag $+45 \mathrm{ml}$ (B8); $420 \mathrm{~g} /$ polybag $+0 \mathrm{ml}$ (B9); $420 \mathrm{~g} /$ polybag +15 $\mathrm{ml}$ (B10); $420 \mathrm{~g} /$ polybag $+30 \mathrm{ml}$ (B11); and $420 \mathrm{~g} /$ polybag $+45 \mathrm{ml}$ (B12). Parameters observed were plant height, stem diameter, number of branches, number of leaves, leaf width, number of flowers, and root dry weight. The results showed that the combination of $420 \mathrm{~g} /$ polybag rice husk biochar and 45 $\mathrm{ml}$ bacteria Paenibacillus sp. affected both the vegetative and generative growth of red chili plants.
\end{abstract}

Keywords: Chili, Ultisol, Biochar, Paenibacillus sp.

\begin{abstract}
ABSTRAK
Cabai merah merupakan komoditas yang harus ditingkatkan di daerah Riau yang sebagian besar merupakan tanah ultisol. Biochar sekam padi sebagai amelioran dapat meningkatkan pertumbuhan tanaman. Begitu juga bakteri Paenibacillus sp. dapat melarutkan fosfat yang tidak tersedia menjadi tersedia bagi tanaman cabai merah. Penelitian ini bertujuan untuk mengetahui dosis terbaik anatar kombinasi biochar sekam padi dan BPF Paenibacillus sp. terhadap pertumbuhan tanaman cabai merah. Penelitian dilaksanakan di Kebun Percobaan Fakultas Pertanian Universitas Riau pada bulan Januari sampai bulan Mei 2021, dilakukan secara RAL non faktorial, kemudian diuji dengan DNMRT. Faktor kombinasinya adalah biochar sekam padi dan BPF Paenibacillus sp.: 0 $\mathrm{g} /$ polybag $+0 \mathrm{ml}(\mathrm{B} 1) ; 0 \mathrm{~g} /$ polybag $+15 \mathrm{ml}(\mathrm{B} 2) ; 0 \mathrm{~g} /$ polybag $+30 \mathrm{ml}(\mathrm{B} 3) ; 0 \mathrm{~g} /$ polybag $+45 \mathrm{ml}$ (B4); $210 \mathrm{~g} /$ polybag $+0 \mathrm{ml}$ (B5); $210 \mathrm{~g} /$ polybag $+15 \mathrm{ml}$ (B6); $210 \mathrm{~g} /$ polybag $+30 \mathrm{ml}(\mathrm{B} 7) ; 210$ $\mathrm{g} /$ polybag $+45 \mathrm{ml}(\mathrm{B} 8) ; 420 \mathrm{~g} /$ polybag $+0 \mathrm{ml}(\mathrm{B} 9) ; 420 \mathrm{~g} /$ polybag $+15 \mathrm{ml}(\mathrm{B} 10) ; 420 \mathrm{~g} /$ polybag + $30 \mathrm{ml}$ (B11); and $420 \mathrm{~g} /$ polybag $+45 \mathrm{ml}$ (B12). Parameter yang diamati adalah tinggi tanaman, diameter batang, jumlah cabang, jumlah daun, lebar daun, jumlah bunga dan berat kering akar. Hasil menunjukkan bahwa pemberian kombinasi $420 \mathrm{~g}$ /polybag biochar sekam padi dan $45 \mathrm{ml}$ BPF Paenibacillus sp. berpengaruh baik terhadap pertumbuhan cabai merah.
\end{abstract}

Kata Kunci: Cabai, Ultisol, Biochar, Paenibacillus sp.

\section{PENDAHULUAN}

Cabai merah (Capsicum annum L.) merupakan komoditas sayuran yang memiliki nilai ekonomi tinggi dan banyak diusahakan oleh petani di dataran rendah sampai dataran tinggi. Cabai merah atau disebut juga cabai besar mempunyai prospek cerah sebagai komoditas yang bernilai ekonomis tinggi 
karena salah satu pemanfaatannya sebagai bahan baku industri. Menurut BPS Riau (2018), produksi cabai besar segar pada tahun 2018 sebesar 17.324 ton.ha $^{-1}$ dengan luas panen cabai besar sebesar 2.309 hektar dan rata-rata produktivitas 7,50 ton.ha ${ }^{-1}$. Dibandingkan tahunsebelumnya, hasil produksi cabai besar tersebut mengalami peningkatan. Pada tahun 2019, produksi cabai merah segar mengalami peningkatan produksi sebesar 17.513 ton.ha- ${ }^{-1}$ dengan luas panen sebesar 2.091 hektar (BPS Riau, 2019). Namun angka hasil produksi ini masih lebih rendah dibandingkan wilayah lain, khususnya Sumatera Barat dimana produksi cabai besar pada tahun 2018 sebesar 106.061 ton.ha ${ }^{-1}$ dengan luas panen 9.642 hektar, dan terus mengalami peningkatan produksi di tahun 2019 sebesar 139.993 ton.ha ${ }^{-1}$ dengan luas panen sebesar 13.227 hektar (BPS Sumbar, 2019). Rendahnya produktivitas ini mendorong pemerintah untuk mengimpor cabai merah dari luar daerah guna memenuhi kebutuhan konsumen yang terus meningkat.

Tanaman cabai merah menjanjikan keuntungan yang besar, tetapi petani masih sulit mengelola dan memanfaatkan lahan yang ada untuk pertanian hortikultura. Hal ini dikarenakan sebagian besar wilayah Riau adalah tanah marjinal, salah satunya adalah lahan ultisol yang memiliki luasan sebesar 2.221.938,38 hektar (BPS Riau, 2017). Tanah ultisol merupakan bagian terluas dari lahan kering di Indonesia, terutama wilayah Riau. Kemasaman yang tinggi, keracunan $\mathrm{Al}, \mathrm{Fe}, \mathrm{Mn}$ dan defisiensi $\mathrm{N}$ dan $\mathrm{P}$ menjadi permasalahan umum pada usaha produksi pertanian tanah ini. Adanya kelarutan aluminium (Al) yang tinggi pada tanah ultisol merupakan kendala utama yang dapat membatasi pertumbuhan tanaman (Idris, 1995). Pengaruh aluminium terhadap tanaman dapat terlihat jelas dengan terhambatnya pertumbuhan akar. Selain itu, kemampuan tanah dalam menahan air rendah dan unsur hara seperti $\mathrm{P}$ yang penting untuk pertumbuhan tanaman kurang tersedia di dalamnya.

Pada umumnya upaya mengurangi kendala yang terdapat pada Ultisol yakni melalui pemberian kapur, bantuan fosfat alam dan bahan organik. Pengapuran dapat menekan kelarutan $\mathrm{Al}, \mathrm{Fe}$, dan $\mathrm{Mn}$ serta menaikkan $\mathrm{pH}$ tanah dan ketersediaan unsur seperti $\mathrm{P}, \mathrm{Ca}$ dan Mo (Idris, 1995). Namun, pendekatan ini kurang ekonomis karena dalam aplikasinya dibutuhkan dalam jumlah yang banyak. Selain itu biaya kebutuhan yang tinggi juga menjadi kendala.

Salah satu upaya yang dapat dilakukan untuk meningkatkan pertumbuhan tanaman di ultisol, yakni dengan penggunaan biochar sekam padi dan BPFPaenibacillus sp..Saat ini biochar sangat diminati karena sangat berpotensi untuk meningkatkan kesuburan tanah, meningkatkan hasil panen dan mampu menyerap serta menyimpan karbon dalam tanah sehingga ramah terhadap lingkungan. Dalam biochar karbon terbentuk dalam proses pirolisis sehingga tidak mudah terdegradasi oleh aktifitas mikroba seperti biomassa lain yang mengandung karbon tingkat rendah. Kualitas biochar tergantung dari jenis bahan dan karakteristik bahan yang digunakan (Shenbagavalli dan Mahimairaja, 2012). Mikroorganisme pelarut fosfat adalah kelompok mikroorganisme yang mampu melarutkan fosfat tidak tersedia menjadi tersedia dan dapat diserap tanaman. Pemanfaatan BPF Paenibacillus sp. diharapkan dapat mengatasi kebutuhan unsur $\mathrm{P}$ pada tanahultisol terhadap pertumbuhan tanaman cabai merah. Pemberian kombinasi biochar sekam padi dan bakteri pelarut fosfat Paenibacillus sp. diharapkan dapat memperbaiki sifat fisik, kimia dan biologi pada tanah ultisol sehingga dapat meningkatkan pembenahan tanah dan mendukung pertumbuhan tanaman cabai merah.

\section{METODOLOGI PENELITIAN}

Penelitian dilaksanakan di Laboratorium Penyakit Tumbuhan dan UPT Kebun Percobaan Fakultas Pertanian Universitas Riau pada bulan Januari-Mei 2021.

Bahan yang digunakan biochar sekam padi, isolat bakteri Paenibacillus sp, Nutrient Agar, media pikovskaya, tanah ultisol dari wilayah Kampar, benih cabai Lado F1, air kelapa, polybag ukuran $40 \mathrm{~cm}$ x $50 \mathrm{~cm}$, aquadest, air, pupuk urea, pupuk TSP, pupuk $\mathrm{KCl}$, Furadan $3 \mathrm{Gr}$, alkohol $70 \%$, aluminium foil, kertas label, kertas tisu, larutan spiritus, plastik warp.

Alat yang digunakan cangkul, garu, parang, timbangan digital, cawan petri, timbangan analitik, jangka sorong, erlenmeyer $250 \mathrm{ml}$, autoclave, inkubator, oven, vortex, tabung reaksi, gelas kimia, gelas ukur, jarum ose, spatula, bunsen, batang pengaduk, panci, 
kompor, ember plastik, gembor, paranet, meteran dan alat tulis. Penelitian dilaksanakan secara RAL faktorial dengan 12 perlakuan kombinasi biochar sekam padi dan BPF Paenibacillus sp., masing - masing diulang 3 kali sehingga diperoleh 36 unit percobaan. Setiap unit terdiri dari 2 tanaman sehingga didapat 72 tanaman yang diamati.

Parameter yang diamati ialah tinggi tanaman, diameter batang, jumlah cabang, jumlah daun, lebar daun, jumlah bunga dan berat kering akar.

\section{HASIL DAN PEMBAHASAN}

\section{Tinggi Tanaman $(\mathrm{cm})$}

Hasil pengamatan tinggi tanaman cabai merah dapt dilihat pada Tabel 1 .

Tabel 1. Rerata Tinggi Tanaman Cabai Merah pada Perlakuan Pemberian Biochar Sekam Padi dan BPF Paenibacillus sp.

\begin{tabular}{cc}
\hline Perlakuan Kombinasi & Tinggi Tanaman $(\mathrm{cm})$ \\
\hline $0 \mathrm{~g} /$ polybag $+0 \mathrm{ml}$ & $18,53 \mathrm{~d}$ \\
$0 \mathrm{~g} /$ polybag $+15 \mathrm{ml}$ & $19,28 \mathrm{~cd}$ \\
$0 \mathrm{~g} /$ polybag $+30 \mathrm{ml}$ & $18,69 \mathrm{~d}$ \\
$0 \mathrm{~g} /$ polybag $+45 \mathrm{ml}$ & $18,70 \mathrm{~d}$ \\
$210 \mathrm{~g} /$ polybag $+0 \mathrm{ml}$ & $19,65 \mathrm{~cd}$ \\
$210 \mathrm{~g} /$ polybag $+15 \mathrm{ml}$ & $20,84 \mathrm{bcd}$ \\
$210 \mathrm{~g} /$ polybag $+30 \mathrm{ml}$ & $23,25 \mathrm{ab}$ \\
$210 \mathrm{~g} /$ polybag $+45 \mathrm{ml}$ & $24,70 \mathrm{a}$ \\
$420 \mathrm{~g} /$ polybag $+0 \mathrm{ml}$ & $18,71 \mathrm{~d}$ \\
$420 \mathrm{~g} /$ polybag $+15 \mathrm{ml}$ & $22,46 \mathrm{abc}$ \\
$420 \mathrm{~g}$ /polybag $+30 \mathrm{ml}$ & $23,54 \mathrm{ab}$ \\
$420 \mathrm{~g} /$ polybag $+45 \mathrm{ml}$ & $24,71 \mathrm{a}$ \\
\hline
\end{tabular}

Angka-angka pada kolom yang diikuti huruf kecil yang sama adalah berbeda tidak nyata menurut uji DNMRT taraf 5\%.

Berdasarkan Tabel 1, pemberian kombinasi biochar sekam padi dan BPF Paenibacillus sp. menghasilkan tinggi tanaman cabai merah yang berbeda nyata. Pemberian 210 - $420 \mathrm{~g} /$ polybag biochar+ $45 \mathrm{ml} \mathrm{BPF}$ Paenibacillus sp. menunjukkan hasil yang terbaik terhadap tinggi tanaman dan berbeda tidak nyata dengan tinggi tanaman pada perlakuan $420 \mathrm{~g} /$ polybag biochar $+15 \mathrm{ml} \mathrm{BPF}$ Paenibacillus sp. dan 210 - $420 \mathrm{~g} /$ polybag biochar $+30 \mathrm{ml}$ BPF Paenibacillus sp., serta berbeda nyata dengan perlakuan lainnya.

Biochar yang dikombinasikan dengan BPF Paenibacillus sp. mampu berinteraksi penuh untuk mendukung pertumbuhan tanaman cabai merah di ultisol. Kondisi ultisol memiliki $\mathrm{P}$ tersedia dengan kriteria yang sedang sehingga pemberian kombinasi biochar sekam padi dan BPF dengan dosis yang tinggi lebih baik peranannya dan tanpa penambahan kombinasi biochar sekam padi menghasilkan tinggi tanaman cabai merah yang lebih rendah. Menurut Widawati dan Suliasih (2006), BPF dapat membantu mengembalikan kesuburan tanah dan sekaligus meningkatkan produksi tanaman. Lupitasari et al (2018) menyatakan bahwa biochar sekam padi berinteraksi baik dengan BPF sehingga meningkatkan kemampuan ultisol dalam memegang air. Air berperan sebagai pelarut dan bahan pereaksi (reaktan) sehingga menciptakan lingkungan yang memungkinkan untuk berlangsungnya berbagai reaksi biokimia pada tanaman sehingga mengalami pembelahan dan perpanjangan sel/jaringan tanaman melalui proses metabolisme seperti respirasi (Lakitan, 2013). Aktivitas ini didukung juga dengan meningkatnya ketersediaan unsur $\mathrm{P}$ dalam tanah, dimana unsur $\mathrm{P}$ tersedia dalam bentuk $\mathrm{H}_{2} \mathrm{PO}_{4}$ diserap oleh akar kemudian diteruskan ke bagian organ tanaman untuk diolah melalui proses asimilasi. Hasil fotosintesis berupa fotosintat dimanfaatkan untuk proses pertumbuhan tanaman secara langsung dan sebagian disimpan sebagai cadangan makanan. Rata - rata tinggi tanaman cabai merah yang tidak diberi kombinasi perlakuan menunjukkan pertumbuhan tanaman yang kerdil dan tidak optimal. Jika diperhatikan sesuai deksripsi cabai Varietas Lado F1 rerata tinggi tanaman tergolong kerdil sehingga belum mencapai tinggi yang optimal. Hal ini dikarenakan kondisi tanah ultisol kurang mendukung pertumbuhan tanaman cabai merah sehingga 
mengalami kahat unsur hara. Kahat unsur hara adalah keadaan tanaman yang kekurangan unsur hara esensial sehingga pertumbuhan atau hasil tanaman terhambat. Aluminum (Al) yang berlebihan dalam tanah akan menyebabkan keracunan pada tanaman (Harahap, 2012). Fosfor adalah salah satu unsur utama yang sangat penting dalam pertumbuhan tanaman dan tidak terdapat secara bebas di alam (Advinda, 2018). Foth (1991) juga menyatakan bahwa kahat $\mathrm{P}$ pada ultisol dapat menghambat pertumbuhan tanaman seperti menyebabkan

tanaman tumbuh kerdil, perubahan warna daun dan pembentukan biji. Pada kondisi ini pemberian biochar sekam padi yang dikombinasikan dengan BPF Paenibacillus sp. sangat diperlukan untuk menyediakan unsur fosfor di dalam ultisol.

\section{Diameter Batang}

Hasil pengamatan diameter batang tanaman cabai merah dapat dilihat pada Tabel 2 .

Tabel 2. Rerata Diameter Batang Tanaman Cabai Merah pada Kombinasi Biochar Sekam Padi dan BPF Paenibacillus sp.

\begin{tabular}{cl}
\hline Perlakuan Kombinasi & Diameter Batang $(\mathrm{mm})$ \\
\hline $0 \mathrm{~g} /$ polybag $+0 \mathrm{ml}$ & $5,39 \mathrm{e}$ \\
$0 \mathrm{~g} /$ polybag $+15 \mathrm{ml}$ & $5,79 \mathrm{de}$ \\
$0 \mathrm{~g} /$ polybag $+30 \mathrm{ml}$ & $5,85 \mathrm{de}$ \\
$0 \mathrm{~g} /$ polybag $+45 \mathrm{ml}$ & $5,77 \mathrm{de}$ \\
$210 \mathrm{~g} /$ polybag $+0 \mathrm{ml}$ & $5,89 \mathrm{de}$ \\
$210 \mathrm{~g} /$ polybag $+15 \mathrm{ml}$ & $6,43 \mathrm{bcde}$ \\
$210 \mathrm{~g} /$ polybag $+30 \mathrm{ml}$ & $6,33 \mathrm{bcde}$ \\
$210 \mathrm{~g} /$ polybag $+45 \mathrm{ml}$ & $7,20 \mathrm{abc}$ \\
$420 \mathrm{~g} /$ polybag $+0 \mathrm{ml}$ & $6,16 \mathrm{cde}$ \\
$420 \mathrm{~g} /$ polybag $+15 \mathrm{ml}$ & $6,75 \mathrm{abcd}$ \\
$420 \mathrm{~g} /$ polybag $+30 \mathrm{ml}$ & $7,77 \mathrm{a}$ \\
$420 \mathrm{~g} /$ polybag $+45 \mathrm{ml}$ & $7,47 \mathrm{ab}$ \\
\hline
\end{tabular}

Angka-angka pada kolom yang diikuti huruf kecil yang sama adalah berbeda tidak nyata menurut uji DNMRT taraf 5\%.

Data Tabel 2 menunjukkan bahwa pemberian kombinasi $420 \mathrm{~g} /$ polybag biochar + $30 \mathrm{ml}$ BPF Paenibacillus sp. diperoleh diameter batang terbesar dan berbeda tidak nyata dengan pemberian $420 \mathrm{~g} /$ polybag biochar+ $15 \mathrm{ml}$ BPF Paenibacillus sp. dan 210 - 420 g/polybag biochar + $45 \mathrm{ml}$ BPF Paenibacillus sp., namun berbeda nyata dibanding dengan perlakuan lainnya.

Pertambahan diameter batang tanaman dipengaruhi oleh ketersediaan nutrisi di dalam tanah dan sifat fisik tanah dalam menyediakan atau mengikat hara serta air sebagai pelarut hara. Ultisol memiliki porositas yang rendah dan memiliki kandungan $\mathrm{Al}$ yang tinggi sehingga diperlukan penambahan biochar dan BPF Paenibacillus sp. sebagai pembenah tanah yang berperan dalam mengikat air dan menyediakan pori - pori serta mengikat unsur $\mathrm{P}$ di dalam tanah sehingga perakaran tanaman dapat berkembang dengan baik dan penyerapan unsur hara berjalan dengan baik ke bagian organ tanaman. Hal ini didukung oleh pernyataan Hamim (2018) bahwa air berperan sebagai pembentuk protoplasma yakni cairan utama penyusun sel, baik yang terdapat di dalam sitoplasma maupun vakuola sel. Kekurangan air sering kali menyebabkan kekurangan hara pada tumbuhan karena kelarutan di dalam tanah menjadi sangat rendah sehingga mengganggu proses reaksi reaksi metabolisme yang mengakibatkan terhambatnya pertumbuhan tanaman. Peningkatan jumlah pori dan kemantapan agregat pada gilirannya akan meningkatkan kapasitas infiltrasi dan sifat aerasi tanah (Dwiastuti et al, 2016). Selain itu, Harahap (2012) menyatakan bahwa kemampuan tanah dalam mengikat air mengaktifkan senyawa senyawa kimia pada tanaman seperti hormon auksin, giberelin dan sitokinin, sehingga proses pembelahan, perpanjangan dan pelebaran sel batang terjadi dan berpengaruh dalam pertumbuhan diameter batang.

Perlakuan tanpa kombinasi biochar dan BPF maupun perlakuan dengan dosis yang rendah menunjukkan diameter batang yang lebih kecil. Hal ini berkaitan dengan terbatasnya ketersediaan unsur hara yang dibutuhkan tanaman sehingga proses 
metabolisme tanaman terganggu, sehingga asimilat yang dihasilkan lebih sedikit dan mengakibatkan pertumbuhan tanaman yang terhambat.

\author{
Jumlah Cabang \\ Hasil pengamatan jumlah cabang cabai \\ merah dapat dilihat pada Tabel 3 .
}

Tabel 3. Rerata Jumlah Cabang Tanaman Cabai Merah pada Kombinasi Biochar Sekam Padi dan BPF Paenibacillus sp.

\begin{tabular}{cc}
\hline Perlakuan Kombinasi & Jumlah Cabang (cabang) \\
\hline $0 \mathrm{~g} /$ polybag $+0 \mathrm{ml}$ & $8,00 \mathrm{f}$ \\
$0 \mathrm{~g} /$ polybag $+15 \mathrm{ml}$ & $9,66 \mathrm{ef}$ \\
$0 \mathrm{~g} /$ polybag $+30 \mathrm{ml}$ & $9,50 \mathrm{ef}$ \\
$0 \mathrm{~g} /$ polybag $+45 \mathrm{ml}$ & $9,00 \mathrm{ef}$ \\
$210 \mathrm{~g} /$ polybag $+0 \mathrm{ml}$ & $11,20 \mathrm{de}$ \\
$210 \mathrm{~g} /$ polybag $+15 \mathrm{ml}$ & $13,25 \mathrm{~cd}$ \\
$210 \mathrm{~g} /$ polybag $+30 \mathrm{ml}$ & $14,29 \mathrm{bcd}$ \\
$210 \mathrm{~g} /$ polybag $+45 \mathrm{ml}$ & $14,45 \mathrm{bc}$ \\
$420 \mathrm{~g} /$ polybag $+0 \mathrm{ml}$ & $12,83 \mathrm{~cd}$ \\
$420 \mathrm{~g} /$ polybag $+15 \mathrm{ml}$ & $14,58 \mathrm{bc}$ \\
$420 \mathrm{~g} /$ polybag $+30 \mathrm{ml}$ & $16,50 \mathrm{~b}$ \\
$420 \mathrm{~g} /$ polybag $+45 \mathrm{ml}$ & $19,50 \mathrm{a}$ \\
\hline
\end{tabular}

Angka-angka pada kolom yang diikuti huruf kecil yang sama adalah berbeda tidak nyata menurut uji DNMRT taraf 5\%.

Data Tabel 3 diketahui bahwa pemberian $420 \mathrm{~g} /$ polybag biochar+ $45 \mathrm{ml} \mathrm{BPF}$ Paenibacillus sp. menghasilkan jumlah cabang terbanyak dan berbeda nyata dengan perlakuan lainnya. Kombinasi biochar dan $\mathrm{BPF}$ Paenibacillus sp. pada dosis tinggi semakin meningkatkan pertumbuhan jumlah cabang tanaman cabai merah sehingga percabangan dan suplai penyimpanan cadangan makanan bagi tumbuhan semakin tersedia sepanjang unsur hara dalam tanah cukup tersedia.

Pada perlakuan tanpa pembenah tanah dan perlakuan yang diberi pembenah tanah dengan dosis yang lebih kecil, jumlah cabang lebih sedikit, hal ini diduga karena keterbatasan unsur hara. Menurut Hardjowigeno (2003) bahwa kekurangan unsur hara fosfor dapat mengakibatkan gangguan pada metabolisme tanaman, diantaranya menghambat pertumbuhan. Kekurangan unsur hara fosfor pada tanaman dapat dicirikan dengan pertumbuhan terhambat seperti tidak bertambahnya jumlah cabang. Pertambahan cabang tanaman dipengaruhi oleh aktivitas metabolisme yang terjadi pada tanaman, misalnya pada proses fotosintesis. Hamim (2018) dan Lakitan (2013) menyatakan, proses fotosintesis yang terjadi dalam tubuh tanaman menghasilkan karbohidrat yang berperan sebagai sumber energi dan substrat dasar bagi sel tumbuhan untuk menghasilkan senyawa lain yang lebih kompleks seperti pati dan selulosa, asam amino dan protein, lipid maupun asam nukleat yang diperlukan untuk pertumbuhan dan perkembangan tumbuhan sehingga proses percabangan pada tanaman meningkat.

\section{Jumlah Daun}

Hasil pengamatan jumlah daun pada tanaman cabai merah dapat dilihat pada Tabel 4. Berdasarkan Tabel 4 diketahui bahwa pada pemberian $420 \mathrm{~g} /$ polybag biochar $+45 \mathrm{ml} \mathrm{BPF}$ Peanibacillus sp. menunjukkan jumlah daun terbanyak dan berbeda tidak nyata dengan perlakuan $210 \mathrm{~g} /$ polybag biochar $+15-45 \mathrm{ml}$ BPF Paenibacillus sp. dan 420 g/polybag biochar+ $0-30 \mathrm{ml}$ BPF Paenibacillus sp., namun berbeda nyata dibanding perlakuan lainnya. Perlakuan tanpa pemberian biochar dan BPF Paenibacillus sp. $0-30 \mathrm{ml}$ menunjukkan jumlah daun berkurang dan pemberian $0 \mathrm{~g} /$ polybag biochar $+45 \mathrm{ml} \mathrm{BPF}$ Paenibacillus sp. menunjukkan hasil jumlah daun terendah. Hal ini dikarenakan rendahnya ketersediaan unsur hara dalam tanah dan tingginya tingkat kehilangan air pada ultisol. 
Tabel 4. Rerata Jumlah Daun Tanaman Cabai Merah pada Kombinasi Biochar Sekam Padi dan BPF Paenibacillus sp.

\begin{tabular}{cl}
\hline Perlakuan Kombinasi & Jumlah Daun (helai) \\
\hline $0 \mathrm{~g} /$ polybag $+0 \mathrm{ml}$ & $24,29 \mathrm{~cd}$ \\
$0 \mathrm{~g} /$ polybag $+15 \mathrm{ml}$ & $24,87 \mathrm{~cd}$ \\
$0 \mathrm{~g} /$ polybag $+30 \mathrm{ml}$ & $24,04 \mathrm{~cd}$ \\
$0 \mathrm{~g} /$ polybag $+45 \mathrm{ml}$ & $22,70 \mathrm{~d}$ \\
$210 \mathrm{~g} /$ polybag $+0 \mathrm{ml}$ & $29,66 \mathrm{bcd}$ \\
$210 \mathrm{~g} /$ polybag $+15 \mathrm{ml}$ & $37,83 \mathrm{abcd}$ \\
$210 \mathrm{~g} /$ polybag $+30 \mathrm{ml}$ & $37,00 \mathrm{abcd}$ \\
$210 \mathrm{~g} /$ polybag $+45 \mathrm{ml}$ & $50,66 \mathrm{abc}$ \\
$420 \mathrm{~g} /$ polybag $+0 \mathrm{ml}$ & $38,29 \mathrm{abcd}$ \\
$420 \mathrm{~g} /$ polybag $+15 \mathrm{ml}$ & $35,25 \mathrm{abcd}$ \\
$420 \mathrm{~g} /$ polybag $+30 \mathrm{ml}$ & $55,41 \mathrm{ab}$ \\
$420 \mathrm{~g} /$ polybag $+45 \mathrm{ml}$ & $61,12 \mathrm{a}$ \\
\hline
\end{tabular}

Angka-angka pada kolom yang diikuti huruf kecil yang sama adalah berbeda tidak nyata menurut uji DNMRT taraf 5\%.

Dalam penelitian ini tanaman cabai merah yang tidak diberi perlakuan biochar meskipun diberikan BPF dalam berbagai dosis rendah menunjukkan lebih cepat kehilangan air karena porositas tanah yang rendah pada ultisol sehingga air dan unsur hara sulit ditembus lebih dalam oleh perakaran tanaman. Air berperan penting sebagai pelarut unsur hara dari tanah ke dalam tubuh tanaman. Ketersediaan unsur hara terlarut tersebut sangat penting untuk fisiologis tanaman dalam pembentukan klorofil, protein, hormon, dan meningkatkan diferensiasi serta pembelahan sel/jaringan melalui proses metabolisme, salah satunya proses fotosintesis (Lakitan, 2013). Semakin baik tanah dalam menyediakan air dan unsur hara, makin baik pula pertumbuhan tanaman. Hasil fotosintesis sebagian akan digunakan oleh organ daun untuk proses metabolisme, sedangkan sisanya akan didistribusikan ke berbagai jaringan yang tidak berfotosintesis seperti batang, akar, dan bunga. Sehingga jumlah daun terus bertambah seiring berlangsungnya daur hidup tanaman (Hamim, 2018). Pemberian kombinasi biochar dan BPF Paenibacillus sp. berpengaruh baik dalam meningkatkan jumlah daun demi kelangsungan proses metabolisme tanaman cabai merah.

\section{Lebar Daun}

Hasil pengamatan lebar daun tanaman cabai merah dapat dilihat pada Tabel 5.

Tabel 5. Rerata Lebar Daun Tanaman Cabai Merah pada Kombinasi Biochar Sekam Padi dan BPF Paenibacillus sp.

\begin{tabular}{cl}
\hline Perlakuan Kombinasi & Lebar Daun $(\mathrm{cm})$ \\
\hline $0 \mathrm{~g} /$ polybag $+0 \mathrm{ml}$ & $2,15 \mathrm{c}$ \\
$0 \mathrm{~g} /$ polybag $+15 \mathrm{ml}$ & $2,26 \mathrm{c}$ \\
$0 \mathrm{~g} /$ polybag $+30 \mathrm{ml}$ & $2,18 \mathrm{c}$ \\
$0 \mathrm{~g} /$ polybag $+45 \mathrm{ml}$ & $2,19 \mathrm{c}$ \\
$210 \mathrm{~g} /$ polybag $+0 \mathrm{ml}$ & $2,31 \mathrm{c}$ \\
$210 \mathrm{~g} /$ polybag $+15 \mathrm{ml}$ & $2,42 \mathrm{bc}$ \\
$210 \mathrm{~g} /$ polybag $+30 \mathrm{ml}$ & $2,51 \mathrm{bc}$ \\
$210 \mathrm{~g} /$ polybag $+45 \mathrm{ml}$ & $2,49 \mathrm{bc}$ \\
$420 \mathrm{~g} /$ polybag $+0 \mathrm{ml}$ & $2,38 \mathrm{c}$ \\
$420 \mathrm{~g} /$ polybag $+15 \mathrm{ml}$ & $2,47 \mathrm{bc}$ \\
$420 \mathrm{~g} /$ polybag $+30 \mathrm{ml}$ & $2,80 \mathrm{ab}$ \\
$420 \mathrm{~g} /$ polybag $+45 \mathrm{ml}$ & $2,97 \mathrm{a}$ \\
\hline
\end{tabular}

Angka-angka pada kolom yang diikuti huruf kecil yang sama adalah berbeda tidak nyata menurut uji DNMRT taraf 5\%.

Berdasarkan Tabel 5 diketahui bahwa pada pemberian kombinasi $420 \mathrm{~g} /$ polybag biochar $+45 \mathrm{ml}$ BPF Paenibacillus sp. menunjukkan hasil pertumbuhan lebar daun yang terbaik dan berbeda tidak nyata dengan kombinasi $420 \mathrm{~g} /$ polybag biochar $+30 \mathrm{ml} \mathrm{BPF}$ Paenibacillus sp., namun berbeda nyata dengan perlakuan lainnya. Pemberian biochar 
$420 \mathrm{~g} /$ polybag $+45 \mathrm{ml}$ BPF Paenibacillus sp. merupakan hasil terbaik, dengan lebar daun $2,97 \mathrm{~cm}$. Hal ini diduga karena terjadinya perbaikan sifat fisik dan kimia tanah yang sejalan dengan peningkatan dosis biochar dan BPF Paenibacillus sp. sebagai sumber bahan organik yang dapat meningkatkan aktivitas pertumbuhan tanaman (Glick, 1995).

Tanaman cabai merah yang tidak diberi biochar dan BPF Paenibacillus sp. menunjukkan tanaman terhambat pertumbuhannya karena kekurangan unsur hara makro.Unsur $\mathrm{P}$ dapat membantu proses asimilasi pada tanaman. Jika kekurangan $\mathrm{P}$ maka pertumbuhan menjadi terhambat, daun menjadi hijau tua dan pembentukan antosianin meningkat dan diferensiasi jaringan terganggu. Lembaran dan tangkai daun menjadi mati dan akhirnya daun rontok (Harahap, 2012). Menurut Elfiati (2005) beberapa bakteri pelarut fosfat tidak hanya mampu meningkatkan ketersediaan unsur $\mathrm{P}$ bagi tanaman tetapi juga dapat menghasilkan berbagai macam zat pengatur tumbuh seperti asam indol asetat dan giberalin yang berpengaruh terhadap pelebaran tanaman. Pemberian kombinasi biochar dengan BPF Paenibacillus sp. membantu mendorong pelebaran pada permukaan daun cabai.
Semakin lebar permukaan daun tanaman, maka meningkatkan proses metabolisme seperti laju fotosintesis sehingga proses pernapasan tanaman yang lebih giat (Harahap, 2012). Hamim (2018) juga menyatakan bahwa luas daun dan jumlah daun menentukan besarnya laju transpirasi pada tumbuhan. Daun yang lebar akan mendapatkan panas laten yang lebih besar sehingga transpirasi juga lebih besar dibandingkan daun yang sempit. Sebagian besar transpirasi terjadi melalui daun. Salah satu fungsi proses transpirasi adalah menjaga stabilitas suhu tumbuhan dan penyerapan unsur hara tanaman sehingga tanaman dapat tumbuh secara optimal (Hamim, 2018). Hasil dari proses ini mendukung pelebaran daun tanaman karena asimilat yang dihasilkan digunakan kembali untuk memenuhi pertumbuhan organ tanaman. Pemberian kombinasi biochar sekam padi dan BPF Paenibacillus sp. berperan dalam pertumbuhan vegetatif cabai merah khususnya pertambahan lebar daun.

\section{Jumlah Bunga}

Hasil pengamatan jumlah bunga pada tanaman cabai merah dapat dilihat pada Tabel 6.

Tabel 6. Rerata Jumlah Bunga Tanaman Cabai Merah pada Kombinasi Biochar Sekam Padi dan BPF Paenibacillus sp.

\begin{tabular}{cl}
\hline Perlakuan Kombinasi & Jumlah Bunga (kuntum) \\
\hline $0 \mathrm{~g} /$ polybag $+0 \mathrm{ml}$ & $1,75 \mathrm{~d}$ \\
$0 \mathrm{~g} /$ polybag $+15 \mathrm{ml}$ & $2,83 \mathrm{~cd}$ \\
$0 \mathrm{~g} /$ polybag $+30 \mathrm{ml}$ & $3,41 \mathrm{~cd}$ \\
$0 \mathrm{~g} /$ polybag $+45 \mathrm{ml}$ & $3,08 \mathrm{~cd}$ \\
$210 \mathrm{~g} /$ polybag $+0 \mathrm{ml}$ & $10,58 \mathrm{bcd}$ \\
$210 \mathrm{~g} /$ polybag $+15 \mathrm{ml}$ & $12,50 \mathrm{bc}$ \\
$210 \mathrm{~g} /$ polybag $+30 \mathrm{ml}$ & $20,16 \mathrm{ab}$ \\
$210 \mathrm{~g} /$ polybag $+45 \mathrm{ml}$ & $24,75 \mathrm{a}$ \\
$420 \mathrm{~g} /$ polybag $+0 \mathrm{ml}$ & $10,50 \mathrm{bcd}$ \\
$420 \mathrm{~g} /$ polybag $+15 \mathrm{ml}$ & $16,66 \mathrm{ab}$ \\
$420 \mathrm{~g} /$ polybag $+30 \mathrm{ml}$ & $15,16 \mathrm{ab}$ \\
$420 \mathrm{~g} /$ polybag $+45 \mathrm{ml}$ & $22,75 \mathrm{a}$ \\
\hline
\end{tabular}

Angka-angka pada kolom yang diikuti huruf kecil yang sama adalah berbeda tidak nyata menurut uji DNMRT taraf 5\%.

Berdasarkan Tabel 6 menunjukkan pemberian biochar sekam padi dan BPF Paenibacillus sp. berbeda nyata terhadap perolehan jumlah bunga tanaman cabai merah. Pemberian kombinasi 210 - $420 \mathrm{~g} /$ polybag biochar $+45 \mathrm{ml}$ BPF Paenibacillus sp. menunjukkan pertambahan jumlah bunga terbanyak dan berbeda tidak nyata dengan pemberian kombinasi $210-420 \mathrm{~g} /$ polybag biochar $+30 \mathrm{ml}$ BPF Paenibacillus sp. dan $420 \mathrm{~g} /$ polybag biochar $+15 \mathrm{ml}$ BPF Paenibacillus sp., serta berbeda nyata terhadap perlakuan lainnya.

Pemberian kombinasi biochar dan BPF Paenibacillus sp. pada ultisol mendukung pertumbuhan dan perkembangan bunga. Tanpa 
pemberian biochar dan BPF menghasilkan jumlah bunga yang sangat sedikit. Menurut Abdurahman et al (2000) peranan bahan organik yang paling besar adalah berkaitan dengan perbaikan sifat fisik tanah, sedangkan terhadap suplai unsur hara bagi tanaman kurang mendapat perhatian karena jumlah unsur haranya relatif kecil dan lambat tersedia. Namun dalam penelitian ini, pemberian biochar yang dikombinasikan dengan BPF Paenibacillus sp. pengaruh baik terhadap batang, cabang dan daun cabai merah sehingga mendorong pembentukan bunga yang baik pula. Kombinasi biochar dan BPF Paenibacillus sp. dapat membenahi dan mengurangi cekaman yang terjadi di dalam ultisol. Winarso (2005) dan Zulputra et al. (2014) menyatakan bahwa pemberian unsur P dalam jumlah yang cukup tersedia berperan dalam proses metabolisme seperti proses fotosintesis yang mendukung pembelahan sel dan pembesaran sel bahkan transfer dan penyimpanan energi di dalam tanaman sehingga mendukung fase generatif, dimana hasil fotosintesis dapat dimanfaatkan untuk pembungaan dan pembentukan biji.

\section{Berat Kering Akar}

Hasil pengamatan berat kering akar tanaman cabai merah dapat dilhat pada Tabel 7.

Tabel 7. Rerata Berat Kering Akar Tanaman Cabai Merah pada Kombinasi Biochar Sekam Padi dan BPF Paenibacillus sp.

\begin{tabular}{cc}
\hline Perlakuan Kombinasi & Berat Kering Akar $(\mathrm{g})$ \\
\hline $0 \mathrm{~g} /$ polybag $+0 \mathrm{ml}$ & $1,72 \mathrm{a}$ \\
$0 \mathrm{~g} /$ polybag $+15 \mathrm{ml}$ & $1,94 \mathrm{a}$ \\
$0 \mathrm{~g} /$ polybag $+30 \mathrm{ml}$ & $1,97 \mathrm{a}$ \\
$0 \mathrm{~g} /$ polybag $+45 \mathrm{ml}$ & $1,78 \mathrm{a}$ \\
$210 \mathrm{~g} /$ polybag $+0 \mathrm{ml}$ & $1,83 \mathrm{a}$ \\
$210 \mathrm{~g} /$ polybag $+15 \mathrm{ml}$ & $1,73 \mathrm{a}$ \\
$210 \mathrm{~g} /$ polybag $+30 \mathrm{ml}$ & $1,95 \mathrm{a}$ \\
$210 \mathrm{~g} /$ polybag $+45 \mathrm{ml}$ & $2,01 \mathrm{a}$ \\
$420 \mathrm{~g} /$ polybag $+0 \mathrm{ml}$ & $1,72 \mathrm{a}$ \\
$420 \mathrm{~g} /$ polybag $+15 \mathrm{ml}$ & $1,98 \mathrm{a}$ \\
$420 \mathrm{~g} /$ polybag $+30 \mathrm{ml}$ & $2,23 \mathrm{a}$ \\
$420 \mathrm{~g} /$ polybag $+45 \mathrm{ml}$ & $2,06 \mathrm{a}$ \\
\hline
\end{tabular}

Angka-angka pada kolom yang diikuti huruf kecil yang sama adalah berbeda tidak nyata menurut uji DNMRT taraf 5\%.

Berdasarkan data Tabel 7 diketahui bahwa pada pemberian biochar sekam padi yang dikombinasikan dengan BPF Paenibacillus sp. menunjukkan hasil yang berbeda tidak nyata terhadap perolehan berat kering akar tanaman cabai merah. Namun perlakuan $420 \mathrm{~g} /$ polybag biochar $+30 \mathrm{ml} \mathrm{BPF}$ Paenibacillus sp. menunjukkan berat kering tertinggi dibanding perlakuan lain.

Pada penelitian ini pertumbuhan akar tanaman cabai merah menyimpang dari kondisi idealnya karena kondisi tanah sebagai tempat tumbuhnya tidak pada kondisi optimal. Kurniawan et al (2016) menyatakan bahwa berat tanaman dipegaruhi oleh tinggi tanaman dan luas daun, semakin tinggi tanaman dan luas daun maka semakin berat akar tanaman akan semakin meningkat. Bustami et al (2012) menyatakan bahwa berat akar tanaman merupakan bobot dari jaringan dan kandungan air yang terdapat pada jaringan tanaman tersebut. Pertumbuhan organ yang baik menyebabkan semakin banyaknya organ tersebut menyerap air maka berat tanaman meningkat.

Penambahan Biochar berperan sebagai pembenah tanah untuk membantu meningkatkan luas perakaran tanaman cabai merah. Akar tanaman dapat dikendalikan oleh sifat genetis dari tanaman, namun dapat pula dipengaruhi oleh kondisi tanah atau media tumbuh tanaman tersebut (Lakitan, 2013). Hasil penelitian Safitri et al (2018) menunjukkan bahwa pemberian biochar mampu meningkatkan berat kering tanaman. Rona et al (2014) juga menyatakan berat kering tanaman cabai rawit meningkat setelah diaplikasikan biochar sekam padi 2,5 ton.ha ${ }^{-1}$. Berat kering tanaman merupakan indikator berlangsungnya pertumbuhan tanaman yang merupakan hasil fotosintesis tanaman karena unsur hara yang diserap oleh akar diteruskan 
ke daun sebelum disebarluaskan ke seluruh bagian tubuh tanaman.

Namun pada penelitian ini kurang menunjukkan pengaruh terhadap akar. Berdasarkan pengamatan, akar tanaman cabai pada ultisol sulit berkembang dan meluaskan area perakaran lebih dalam sehingga akar tumbuh secara horizontal menyebar dilapisan atas tanah tersebut. Hal ini di duga nutrisi yang ditambahkan ke dalam tanah baik melalui pemberian biochar dan BPF Paenibacillus sp. belum tercukupi atau sedikitnya kandungan hara di dalam ultisol sehingga tidak tersedia dan serapan hara menjadi tidak optimal bagi perakaran cabai merah. Hal ini didukung oleh pernyataan Advinda (2018) bahwa absorbsi air dan garam mineral banyak dilakukan oleh bulu-bulu akar. Bulu-bulu akar sangat berperan memperluas permukaan akar dan memudahkan tanaman mengabsorbsi garam-garam mineral. Namun, proses ini dipengaruhi oleh suhu, kebasahan tanah, dan ventilasi tanah. Garamgaram mineral yang di absorbsi oleh akar adalah dalam bentuk kation dan anion. Hal ini menyebabkan terjadinya pertukaran ion antara akar dan tanah. Jika kation masuk ke dalam akar karena adanya tarikan suatu anion, maka ada kemunginan juga suatu anion di dalam akar tertarik ke luar oleh suatu kation yang terdapat di dalam tanah. Terbatasnya unsur hara inilah yang membuat perakaran tumbuh tidak optimal sementara proses metabolisme yang terjadi diatas permukaan tanah harus terus berlangsung demi kelangsungan hidup tanaman.

\section{KESIMPULAN DAN SARAN}

\section{Kesimpulan}

1. Kombinasi biochar sekam padi dan BPF Paenibacillus sp. tidak berpengaruh terhadap berat kering akar tanaman cabai merah namun dapat meningkatkan tinggi tanaman, diameter batang, jumlah cabang, jumlah daun, dan lebar daun serta jumlah bunga.

2. Pemberian $420 \mathrm{~g} /$ polybag biochar sekam padi $+45 \mathrm{ml}$ BPF Paenibacillus sp. per tanaman berpengaruh baik terhadap tinggi tanaman, diameter batang, jumlah cabang, jumlah daun, lebar daun dan jumlah bunga tanaman cabai merah.

\section{Saran}

Pada penelitian cabai merah dapat disarankan menggunakan biochar sekam padi $420 \mathrm{~g} /$ polybag dan BPF Paenibacillus sp. 45 $\mathrm{ml}$ dan untuk penelitian lanjutan dilakukan pengamatan hingga tahap produksi dengan menggunakan dosis yang lebih tinggi untuk memperoleh pengaruh pemberian yang lebih optimal terhadap tanaman cabai merah.

\section{DAFTAR PUSTAKA}

Abdurahman, Fahim, dan Susanti. 2000. Pemanfaatan Berbagai Bahan Organik sebagai Suplemen dalam Peningkatan Produktivitas Lahan. Makalah Hasil Penelitian Buku I. Balitpa, Sukamandi.

Advinda, L. 2018. Dasar-dasar fisiologi tumbuhan. Penerbit Deepublish, Yogyakarta.

Badan Pusat Statistik Riau. 2017. Provinsi Riau dalam Angka 2017. CV.MN Grafika, Pekanbaru.

Badan Pusat Statistik Riau. 2018. Statistika Tanaman Sayuran dan Buah-buahan Provinsi Riau. CV.MN Grafika, Pekanbaru.

Badan Pusat Statistik Riau. 2019. Produksi Tanaman Sayuran Menurut Kabupaten/Kota dan Jenis Tanaman di Provinsi Riau. CV.MN Grafika, Pekanbaru.

Badan Pusat Statistik Sumatera Barat. 2019. Produksi Tanaman Hortikultura Provinsi Sumatera Barat. CV.Graphic Dwipa, Padang.

Bustami,Supardi dan Bakhtiar. 2012. Serapan Hara dan Efisiensi Pemupukan Fosfat serta Pertumbuhan Padi Varietas Lokal. Jurnal Managemen Sumberdaya Lahan, 1(2): $159-170$.

Dwiastuti, S., Maridi, Suwarno, dan Dewi Puspitasari. 2016. Bahan Organik Tanah di Lahan Marjinal dan Faktor-faktornya yang mempengaruhinya. Proceeding Biology Education Conference, 13(1): $748-751$

Foth, H.D. 1991. Dasar - Dasar Ilmu Tanah. UGM Press, Yogyakarta.

Glick, B. R. 1995. The enhancement of plant growth by free living bacteria. Canadian Journal Microbiology, 41: 109 - 117.

Hamim. 2018. Buku Fisiologi Tumbuhan 1: Air, Energi, dan Metabolisme Karbon. Penerbit IPB Press, Bogor. 
Harahap, F. 2012. Fisiologi Tumbuhan Suatu Pengantar. UNIMED Press, Medan.

Hardjowigeno, S. 2003. Ilmu Tanah. Akademik Pressindo, Jakarta.

Idris. 1995. Evaluasi Pemberian Fosfat Alam dari Jawa dan Pengapuran Pada Tanah Masam I Modifikasi Ciri Kimia Tanah. Jurnal Ilmu Pertanian, 5(2): 57 - 62.

Kurniawan, A., Budi Haryono, Medha Baskara dan Setyono S.T. 2016. Pengaruh Penggunaan Biochar pada Media Tanam Terhadap Pertumbuhan Bibit Tanaman Tebu (Saccharumofficinarum L.). Jurnal Produksi Tanaman, 4(2): 153 - 160.

Lakitan, B. 2013. Dasar-dasar Fisiologi Tumbuhan. PT. Raja Grafindo Persada, Jakarta.

Lupitasari, E., Sidik Y., Andrian P. dan Wawan. 2018. Utilization of Biochar and Biofertilizer to Improve Water Holding Capasity and Availability of Phosphorus in Ultisol Land with Soybean Indicators. Journal of Agrotechnology (Tidak dipublikasikan).

Prasad, M., A. Chrysargyris, N.M. Daniel, A. Kavanagh, N.S. Gruda, and Nikolaus T. 2020. Plant Nutrient Availability and $\mathrm{pH}$ of Biochar and Their Fraction with The Possible Use as a Component in A Growing Media. Agronomy Journal, 10(1): 10 .

Rona, Y. 2014. Penggunaan Kompos dan Biochar untuk Pembibitan, Pertumbuhan dan Hasil Cabai Rawit (Capsicum annum L). Fakultas Pertanian, 2(2): 1 8.
Safitri, I.N., C.S. Tri, dan B. Cahyadi. 2018. Biochar dan Kompos untuk Peningkatan Sifat Fisika Tanah dan Efisiensi Penggunaan Air. Techno : Jurnal Penelitian, 7(1): 116 - 127.

Santi, L.P., dan D.H. Goenadi. 2010. Pemanfaatan Bio-char sebagai Pembawa Mikroba untuk Pemantap Agregat Tanah Ultisol dari Taman Borgo - Lampung. Menara Perkebunan, 78(2): $52-60$.

Shenbagavalli, S. dan Mahimairaja, S. 2012. Production and characterization of biochar from different biological wastes. Internasional Journal of Plant, Animal, and Environtmental Sciences, 2 (1) : 197 -201 .

Widawati, S., dan Suliasih. 2006. Augmentasi bakteri pelarut fosfat (BPF) potensial sebagai pemacu pertumbuhan caysin (Brasica caventis Oed.) di tanah marjinal. Biodiversitas, 7(1): $10-14$

Winarso, S. 2005. Kesuburan Tanah. Penerbit Gava Media, Yogyakarta.

Zulputra, Wawan dan Nelvia. 2014. Respon Padi Gogo (Oryzasativa L.) Terhadap Pemberian Silikat dan Pupuk Fosfat pada Tanah Ultisol. Jurnal Agroteknologi, 4(2): 1 - 10. 